Campos, A. C., Mendes, J., Valle, P. O. d., \& Scott, N. (2016). Co-Creation

Experiences: Attention and Memorability. Journal of Travel \& Tourism Marketing.

Published online January 18, 2016

\title{
CO-CREATION EXPERIENCES: ATTENTION AND MEMORABILITY
}

\begin{abstract}
This study examines on-site co-creation experiences from a tourist perspective. A review of the relevant literature and in-depth interviews with 22 tourists who participated in a 'swimming with dolphins' experience are used to explore the importance of active participation and interaction in enhancing tourist attention and the memorability of the experience. Findings show that high levels of attention and memorability have been associated with particular cognitive and physical activities and interactions during the overall experience, and suggesting that on-site co-creation influences memorability by focusing a visitor's attention. This study contributes both to the understanding and conceptualization of co-creation experiences in the field of tourism by substantiating the usefulness of a psychologically-based approach to experience design.
\end{abstract}

KEYWORDS. Co-creation tourism experience, active participation, interaction, attention, memorability 


\section{CO-CREATION EXPERIENCES: ATTENTION AND MEMORABILITY}

\section{INTRODUCTION}

Recent research on tourism experiences stresses the role of tourists as co-creators of their own experience (Prebensen, Vittersø, \& Dahl, 2013a; Tan, Kung, \& Luh, 2013) and that tourism organizations and destinations need to deliver memorable experiences (Neuhofer, Buhalis, \& Ladkin, 2012). These trends are leading businesses (Ramaswamy \& Gouillart, 2010) and destinations (Jager, 2009; Kreziak \& Frochot, 2011; Prebensen \& Foss, 2011) to involve customers in the design, production, and consumption of experiences. Experiences are considered desirable due to their contribution to the meaning of individuals' lives (Pine \& Gilmore, 1999) as they connect the affective, cognitive, and behavioural dimensions on a moment-to-moment basis (Schmitt, 1999; Scott, Laws, \& Boksberger, 2009).

Delivery of memorable experiences is central to an experience economy (Pine \& Gilmore, 1999; Voss, 2004; Dalton, Lynch, \& Lally, 2009; Gibbs \& Ritchie, 2010) and to tourism where "the end goal of a tourist experience is to create lasting memories that a visitor will reminisce about and will share in respective social networks" (Andrades \& Dimanche, 2014, p. 108). The concept of "memorable experience" has been operationalized as "the tourism experience positively remembered and recalled after the event has occurred” (Kim, Ritchie, \& McCormick, 2012, p. 13).

Experiences emerge from activities and interactions during consumption (Poulsson \& Kale, 2004) and rich and vivid memories are part of their essence (Cutler \& Carmichael, 2010; Pikkemaat \& Schuckert, 2007; Tung \& Ritchie, 2011a). Holidays may only last a fortnight but can linger in one’s memory for a life-time (Marschall, 2012), are associated with memorabilia (Ferdinand \& Williams, 2010) and narration of stories (Cary, 2004), and contribute to ongoing meaning, identity formation (Tung \& Ritchie, 2011b) and ego sustainment (Oana, 2008). Experience memorability is connected to novelty, extraordinariness, spontaneity, unexpectedness (Andrades \& Dimanche, 2014; Cary, 2004; Kim et al., 2012), as experiences involve a temporary rupture of everyday reality (Andrades \& Dimanche, 2014), and are "in sharp contrast or opposition to the daily experience” (Quan \& Wang, 2004, p. 300). As memories are the outcome of experiences, 
they are influential factors in future consumption habits (Cutler \& Carmichael, 2010; Wright, 2010) and decisions about where to travel or to repeat visit (Lehto, O’Leary, \& Morrison, 2004; Braun-LaTour, Grinley, \& Loftus, 2006; Kim, 2010; Marschall, 2012).

Tourism experiences can be both mentally and physically engaging and lead to focused attention, encoding and memorability (Hunter, 1994; Kuhl \& Chun, 2014; Mulongo, 2013). Active participation, interaction and attention are considered paths to improve experience memorability (Brunner-Sperdin, Peters, \& Strobl, 2012; Moscardo, 1996). Notwithstanding the strategic role of attention (Davenport \& Beck, 2000; Hoffman \& Ocasio, 2001; Ocasio, 1997, 2011) in co-creating experiences (Andrades \& Dimanche, 2014), the theme has received little consideration by tourism scholars (Ooi, 2003). Attention attractors and distractors are inherent to the tourist experience and need to be identified and effectively managed (Ooi, 2010), so that experiential propositions are perceived as different and enticing (Falkinger, 2003).

Attention is a collection of neural and cognitive processes which have behavioural effects and are part of daily activity (Dayan, Kakade, \& Montague, 2000). Attention is related to perception and memory (Mather, 2013; Kuhl \& Chun, 2014; Shaffer \& Kipp, 2014), and its importance in human behaviour and everyday life has stimulated research in social psychology (Mundy \& Newell, 2007), neuroscience (Sarter, Givens, \& Bruno, 2001), education (Sylwester \& Cho, 1993; Mulongo, 2013), economics (Brooks, 1996), management (Cho \& Hambrick, 2006; Yadav, Prabhu, \& Chandy, 2007), visitor management (Bitgood, 2010), and recently in tourism (Niculescu, 2010; Ooi, 2010). Memory is limited in capacity (Chun \& Turk-Browne, 2007) and attention is an important influencer of what will be encoded and recalled (Kuhl \& Chun, 2014). Learning outcomes and memory are dependent on the degree of attention an individual pays to a subject (Scerif \& Wu, 2014). Further, attention to exhibition and museum displays leads to visitors’ satisfaction (Bitgood, 2010).

To date there are few psychological studies which have examined the tourist's engagement in on-site co-creation experiences (Campos, Mendes, Valle \& Scott, 2015; Andrades \& Dimanche, 2014). This study aims at filling this gap by exploring and integrating a psychological perspective (Larsen, 2007) through examination of attentional processes and their influence on memorability. Co-creation is here understood as requiring the tourist's active participation and interaction during the on-site experience, 
thus highlighting two perspectives: one, emphasising active participation in events which have the tourist in the centre of a network of players in the experience environment; and the other considering particular experiences that mobilize the tourist to engage in relations with others. Thus, active participation and interaction with people are considered two key dimensions of co-creation (Campos et al., 2015).

This research addresses the following questions: how do tourists perceive active participation and interaction during experience, how do they describe their attentional processes and their relation to active participation and interaction, and is the memorability of the experience related to active participation, interaction and attention? These questions are explored through in-depth interviews during a highly engaging and interactive experience: swimming with dolphins. The paper firstly discusses co-creation in the tourism literature and current issues on attention addressed by diverse fields of science. It then outlines the research methodology, describes the case analysed, reports and discusses relevant findings. Theoretical and practical implications for tourism are derived from this research.

\section{LITERATURE REVIEW}

\section{Tourism Co-creation}

We may distinguish two main approaches to co-creation in the literature. Firstly, co-creation may be discussed as a process of interrelated interactions and activities that connects the tourist and other actors, and experiences are the context in which those interactions and activities occur (Bertella, 2014; Bharwani \& Jauhari, 2013; Binkhorst \& Den Dekker, 2009; Mathisen, 2013; Mehmetoglu \& Engen, 2011; Mossberg, 2007; O’Dell \& Billing, 2005; Volo, 2009). These interactions and activities generate value for the customer (Potts, Hartley, Banks, Burgess, Cobcroft, Cunningham, \& Montgomery, 2008; Ramaswamy, 2011). From this point of view, co-creation can occur before travel, during a stay at the destination, and after the travel (Binkhorst \& Den Dekker, 2009; Rihova, Buhalis, Moital, \& Gouthro, 2014; Rihova, Buhalis, Moital, \& Gouthro, 2013). For example, an online program to help in designing a holiday itinerary may be of value to a customer and in providing such an interactive online system, the supplier is cocreating value. This perspective on co-creation is found in current management, consumer behaviour and marketing research and underpins the concepts of the experience economy, the performance turn, and S-D Logic (Arnould \& Price, 1993; Holbrook \& Hirschman, 
1982; Perkins \& Thorns, 2001; Pine \& Gilmore, 1999; Prahalad \& Ramaswamy, 2004; Vargo \& Lusch, 2004, 2008). This understanding of co-creation dominates the tourism literature (Neuhofer, Buhalis, \& Ladkin, 2013).

A second perspective focuses on the particular tourism experience as enacted insitu (Prebensen \& Foss, 2011). Here co-creation is discussed as occurring during the tourist's active participation and interaction with others during the consumption experience. This interpretation is closely related to current ideas of the performance turn (Perkins \& Thorns, 2001), the tourist's agency (Kreziak \& Frochot, 2011), skilled consumption, and more recently to creative tourism (Richards, 2010; Richards \& Marques, 2012). This perspective is more closely related to tourists, how they choose to practice tourism and express themselves through their own tourism experiences.

This study adopts the second perspective, a co-creation in consumption approach, concentrating on the tourist's subjective experience as a set of psychological processes and events that take place during performance-based activities and interaction with people at the experience environment. This psychological perspective conceptualizes experience as involving cognitive processes, which are connected to different stages of the overall tourism experience (Larsen, 2007). Thus the definition of co-creation tourism experience adopted in this paper is:

a co-creation tourism experience is the sum of the psychological events a tourist goes through when contributing actively through physical and/or mental participation in activities and interacting with other subjects in the experience environment.

\section{Co-creation experience involves active participation}

Travel to destinations involves participation in activities (Edensor, 2000) that are perceived as exciting and different from routines (Wikstrom, 2008). This participation generates interest and contributes to creation of meaning derived from the travel holiday (Ryan, 2000). Traditional practices of tourism have been informed by the gaze paradigm (Urry, 1990). Under this paradigm, tourism encompasses a particular way of perceiving the world influencing simultaneously what is seen and the way of seeing (Perkins \& Thorns, 2001). Urry's (1990) characterized mass consumption tourism through the gaze because prevailing tourist activities involved the eye and visual perception. Visiting 
historical landmarks, contemplating landscapes, going to famous attractions are activities requiring sightseeing at particular sites (Pagenstecher, 2003).

Though Urry's sociological point of view was expedient for describing patterns of mass tourism consumption and understood tourism dynamically as social construction of meaning, it was criticized on account of the conception of the tourist as "a passive sightseer consuming sites in prescribed fashions” (Ek, Larsen, \& Hornskov, 2012, p. 126). The performance turn (Mansfeldt, Vestager \& Iversen, 2008) introduced a new perspective which claims the need to overthrow a representation "too passive" to accurately describe contemporary tourist behaviour and consumption.

According to this turn, tourists have evolved towards active participation and multi-sensory exploration, "ideas of active bodily involvement; physical, intellectual and cognitive activity and gazing” (Perkins \& Thorns, 2001, p. 193). A visitor thereby becomes an involved experience authenticator, a more appealing proposition than merely watching others' performances (Mkono, 2012). One’s “own activity” “results from doing, interest and engagement" and a decisive contributor to experiences, bestowing experiential content on the activity itself (Wikstrom, 2008). Here the tourist is someone who wants to interact, actively learn and apply knowledge, more than watch other people (Tan et al., 2013; Tan, Luh, \& Kung, 2014). There is a growing interest in understanding people as experiencers rather than as receivers of messages, as creators of meaning rather than interpreters, and as actors rather than observers (O'Dell, 2007).

Experiences therefore arise from activities (Ooi, 2003) and increasingly involve active participation of the tourist (Aho, 2001; Mkono, 2012). This active participation asks for the use of personal skills and resources (Aho, 2001), and stimulates personal and/or collective identity (Kreziak \& Frochot, 2011; Lugosi \& Walls, 2013). Engaged participation in stimulating activities, either in physical terms or mental, leads to memorable experiences (Wikström, 2008). This helps to explain "the growing interest in participative and extreme sports, and in new types of cultural, adventure, and creative tourism” (Azevedo, 2009, p. 4), participation in science, arts or crafts workshops (Bertella, 2014; Richards, 2010), interactive cultural experiences (Minkiewicz, Evans, \& Bridson, 2013), and animal-based interaction (Bertella, 2014).

\section{Co-creation experience involves social interaction}


Social interactions are a central part of tourism experiences (Cutler \& Carmichael, 2010) and consequently, that they have a social dimension and meaning (de Rojas \& Camarero, 2008; Kreziak \& Frochot, 2011; Morgan, 2007). In the context of the increasing demand for more creative forms of tourism (Richards, 2010; Richards \& Wilson, 2006), co-creation experiences include “outer interactions” with the experience environment, people, and activities (Bertella, 2014; Mehmetoglu \& Engen, 2011; Tan et al., 2013, 2014). On-site experiences engage the individual at different levels, namely physically, emotionally and intellectually (Verhoef, Lemon, Parasuraman, Rogeveen, Tsiros, \& Schlesinger, 2009) but also socially, as they foster interpersonal interaction insitu (Arnould \& Price, 1993; Prebensen \& Foss, 2011). These interactions bring together all influencers of the tourist experience (Prebensen et al, 2013a). Some interactions are planned, such as an encounter between a craft instructor and a tourist at a workshop, while others just happen as a result of a particular context or setting, e.g. tourists talking to each other during the workshop. They may be formal involving a written agreement between parties, e.g. a hotel owner and a guest, or informal encounters, like a casual conversation with a fellow countryman in a restaurant.

Interactions are constituents of human social behaviour (Stangor, Jhangiani \& Tarry, 2014) and can be described in terms of the degree of the individual's closeness to others (Surra \& Ridley, 1991). How people feel connected to others, how they perceive the relationship with family members, spouses or friends is seen as influencing the behavioural, affective and cognitive dimensions of encounters and relationships (Stangor et al., 2014). For instance, partners who perceive themselves as very close to one another, feel as they were a single entity, expressed by "we", and tend to communicate more empathetically. On the other hand, the sense of closeness develops as people experience proximity and share intimacy, namely through expression of emotionally-charged thoughts (Aron, Melinat, Aron, \& Vallone, 1997).

As interactions are sources of experiences (Minkiewicz et al., 2013), the interplay between individuals becomes an important influencer of the experience (Walls, Okumus, Wang, \& Kwun, 2011). People expect to derive pleasure from socializing (De Rojas \& Camarero, 2008; Kreziak \& Frochot, 2011) and to live emotional moments with others (Correia \& Crouch, 2004), even though realizing the transient nature of relationships (Culter \& Carmichael, 2010; Rihova et al., 2013) or the fact that they may involve strangers (Ballantyne, Packer, \& Falk, 2011). They desire to sense flow, belonging or 
communitas (Arnould \& Price, 1993; Cary, 2004b; Morgan, 2007a, 2007b; Schmitt, 2010). Contacts with others during experience have been considered an important factor contributing to exploring individual creativity (Ballantyne et al., 2011; Ihamäki, 2012) or to succeed in achieving individual goals and projects (Arnould \& Price, 1993; Kreziak \& Frochot, 2011; Rihova et al., 2013).

\section{Attention}

Attention is an important research topic as it influences both people and organisations, affecting the way individuals perceive and interact with the environment, and thus how personal biography evolves and group and social dynamics unfold. Attention encompasses cognitive activities (such as information processing), physical responses resulting from human physiology (e.g. movements of the eye), and neural activity (neuron activation in brain systems) and by this reason it is viewed as a complex phenomenon built on interconnected processes (Dayan et al., 2000, Ocasio, 2011). Beyond greatly impacting learning and educational performance (Scerif \& Wu, 2014), professional realization and biographical memory, it also generates effects on social behaviour, academic achievement, and business management.

Research on attention emphasises its dynamic nature. Attention is commonly defined as the selection of particular stimuli out of the many pervading and environment, for that reason facilitating mental processing of some while inhibiting others (Chun \& Turk-Browne, 2007; Clark, 1997; Ocasio, 2011; Robinson, 2001). Selective attention sometimes is called focus (Bitgood, 2010). Attention is a scarce resource (Davenport \& Beck, 2001, Dijksterhuis \& Aarts, 2010; Huberman \& Wu, 2008) in face of limited information processing capacity and an overload of environmental stimuli (attention scarcity). Both factors cause people to select and concentrate on stimuli which are either salient or perceived as particularly relevant in a situation (Ocasio, 2011). As individuals find difficulty in concentrating effectively on two things at the same time, and instead they are processed one at a time (attention selection) according to their perceived importance. Attention shifting requires temporary mental engagement in choosing amongst foci of attention; these changes guide active behaviour and decision making, and are important adaptive strategies to external changes.

Attentive behaviour is triggered in two ways: through bottom-up, exogenous or push stimuli in the environment that reach the perceptual apparatus; and an individual's 
top-down or endogenous mental activities (Dijksterhuis \& Aarts, 2010; Ocasio, 2011). The first category includes involuntary attentional responses as consequence of stimulus saliency (Bitgood, 2010) and the second refers to personal goals, "the mental representation of behaviours or behavioural outcomes that are associated with positive affect” (Dijksterhuis \& Aarts, 2010). Highly salient stimuli in the environment influences the orientation of attention (Kuhl \& Chun, 2014). When goals direct attention, the amount and duration an individual devotes to stimuli depends on which goals are active in a particular situation (Clark, 1997). The amount and duration of attention are a consequence of a continuous process of balance between focus (of attention) and diversion (of attention).

\section{Attention and memory}

The relationship between attention and memory is discussed in cognitive psychology and neuroscience. Evidence from these fields indicates that attention influences memory, and memory, in turn, influences attention (Chun \& Turk-Browne, 2007; Kuhl \& Chun, 2014). Indeed, researchers consider that attention and memory are interdependent systems since recollection is itself a form of attention, in as much as memory involves internally oriented attention. Moreover, active mental engagement which incorporates strategic allocation of attention yields greater probability of successful recollection (Kuhl \& Chun, 2014).

Memory is limited in capacity (Kuhl \& Chun, 2014), imposing constraints on attentional processes (Robinson, 2001). Attention is an important influencer of what will be encoded and recalled; division of attention compromises encoding. Memory depends on externally oriented attention even if attentive behaviour is not related to explicit motivation to form long-term memories (Kuhl \& Chun, 2014). Test results consistently show that learning depends on attentive behaviour (Scerif \& Wu, 2014). The interplay between attention, memory and learning develops by virtue of the role played by attention in the selection of learning materials to be processed and included in long-term memory (Scerif \& Wu, 2014). In short, attention is a step towards memory (Mancas \& Le Meur, 2013), and it is "uncontroversial that attending to or focusing on a fact or event will enhance the likelihood of later memory” (Chun \& Turk-Browne, 2007, p. 177). Social cognition theory also accepts the influence of attention on memorability by explaining 
through observational learning that children's imitative behaviour relative to their parents' is a function of paying attention to their activities (Bandura, 1989).

\section{METHODOLOGY}

\section{Research Setting}

This research was conducted at Zoomarine in Albufeira, Portugal, a marine life and water theme park that offers visitors fun, entertainment and environmental education in a wide variety of activities and spaces. This park was chosen as setting of this study because it offers the Dolphin Emotions Experience, a one and a half hour activity conceived to stimulate visitors' active participation and interaction with marine animals (the dolphins), trainers, instructors, and other participants in a secluded area and atmosphere. Zoomarine is one the two theme parks in Europe providing this kind of interactive encounter with the dolphins.

\section{Data Collection Method}

Qualitative interviews are a data collection tool adequate to a qualitative research design (Finn, Elliott-White, \& Walton, 2000; Jennings, 2005; Jordan \& Gibson, 2004) and their administration is based on the assumption that human subjects are able to account for their own experiences and meanings, shape situations and events and are not mere passive responders to external stimuli (Walle, 1997; Surra \& Ridley, 1991, Finn, Elliot-White \& Walton, 2000). They are also considered suitable for developing knowledge, understanding, and learning, because their adoption allows an exploratory stance at phenomena (Jennings, 2005). The rich information gained from interviews is of great value for the development of a subsequent quantitative data collection instrument (Dong \& Siu, 2013; Leech \& Onwuegbuzie, 2007).

In this study, primary data were obtained from semi-structured in-depth interviews conducted to examine how tourists expressed and reflected on their behaviour, perceptions and thoughts during the on-site co-creation experience. The sampling procedure adopted the purposive sampling method, which is adequate to the study of a population with a characteristic (demographic, attitudinal, experiential, or other) relevant to the research's objectives or who is knowledgeable on the research topic (Jennings, 2005; Morse, Olson, \& Spiers, 2002; Ritchie \& Lewis, 2003). In the present case, tourists participating in the Dolphin Emotions Experience were considered in the best position to 
provide rich information on the research topics. Respondents were chosen to have a mix of gender, nationality and country of origin. As seen in Table 2, tourists from Portugal contributed approximately $30 \%$ of the respondents, while the remaining $70 \%$ were international tourists from Spain, UK, Germany, and Netherlands. There were approximately equal numbers of male and female respondents. In sum, respondents were national or international tourists over 18 years old who participated in the Dolphin Emotions Experience.

Interviews were conducted between May $5^{\text {th }}$ and $17^{\text {th }}$ (Easter season) and immediately after an individual finished the experience. There is a significant increase in visitors' arrivals to the Algarve region at Easter allowing efficient respondent recruitment. Conducting the interviews immediately after the conclusion of the experience allowed rich and vivid information to be collected from participants, and in a context where they were allowed free time to relax, talk freely, in a friendly atmosphere and without time constraints.

\section{Interviewing Process}

The interviewing process followed Lincoln and Guba's (1985) five-step process, however researchers also took into consideration Jennings' (2005) guidelines to qualitative interviewing. Standard procedures were followed to ensure all formal and necessary approvals were obtained from the park managers. Meetings with the Human Resources Director and the Marketing Manager ensured the organization was informed about the research project, the objectives, and the planned schedule for fieldwork.

Preparation for the interviews involved several procedures and decisions. First, the researchers met with the experience general manager, the instructors and the trainers, in order to get acquainted with procedures, sequence of events, activities and the experience environments. Informal conversations took place before the interviewing process with these inside informants, to clarify the purpose of the experience from the park's perspective. These gatekeepers were very important for researchers to gain access to potential interviewees (Jennings, 2005). They also facilitated the collection of information about participants' general characteristics, behaviours and expectations. The researchers were informed about the participants' high expectations towards the Dolphin Emotions Experience, which were explained as a consequence of a desire to accomplish a lifetime dream related to enjoying a close encounter with these animals. 
Secondly, one of the researchers participated in the experience to facilitate a rapport with the interviewees, and thus stimulate the reciprocity process during interviews. Furthermore, interpretive listening, probing and elicitation of relevant information (Jennings, 2005) were considered more effectively achieved if researchers were acquainted with the experience under study. During interviews, researchers applied active, interpretive, and process listening, as recommended by Jennings (2005). As interviews were recorded, communication materials were composed of transcriptions of oral communication, and some notes were taken regarding paralinguistic communication captured during recording (voice pitch, volume, pauses, laughter). Additional considerations were duly attended to, namely those involving research ethics. The interviewees have been asked to participate in the study, after being informed of its nature and purpose. They all gave their written consent to participate and to tape record the interviews. The duration of the conversations, ranging from 30 to 60 minutes, depending on the responses from the participants, was found sufficient to allow all relevant information to emerge and achieve data saturation. Interviews were conducted by the researchers in Portuguese with Portuguese nationals and in English with international tourists.

The interviews were conducted to explore active participation and interaction during and on-site experience, concentrating on attention and memorability. The themes chosen for analysis were identified as experience activities and interactions, attention, and memorability.

Interviews proceeded in three moments, corresponding to a three-section script. The opening moment included a set of introductory questions about the overall visit to Zoomarine and motivations to participate in the Dolphin Emotions Experience. In the second phase, the interviews were conducted based on open-ended questions focusing on the research themes. Table 1 below shows themes, examples of questions asked in this phase and literature sources. Questions on active participation were influenced by Wikström’s (2008) notion of “own activity” and Mathisen’s (2013) “tourist performance” and participants were asked to describe their activities and performances; questions about interaction were induced by Mathisen’s (2013) conception of “social bonding” as "group interaction" and "like-minded individuals" and were requested to identify subjects they interacted with and describe the nature and purpose of such interactions. 
Attention was approached using questions evoked by Bitgood's (2010) concept of focused and engaged attention, and the relationship between active participation and attention (Patterson and Bitgood, 1988). Participants were asked about their foci and moments of attention, how they identify their attentive behaviour and reasons for paying attention. Questions on experience memorability were informed by Tung and Ritchie’s (2011a) study and Kim et al.'s (2012) work on memorable tourism experiences. Subjects were asked to report in detail most memorable events and experiential aspects assuming Reisberg, Heuer, McLean and O'Shaughnessy’s (1988) claim that vivid memories are rich in recalled minutiae; afterwards they were stimulated to discuss active participation and interactions as factors contributing to memorability.In order to gain a broader understanding of perceptions about the constructs and themes under study, participants were also asked to assess them using bipolar scales with the attributes "very low" (represented in the scale by the number 1) and "very high" (represented by the number 10). Results are presented in Table 3. The interview process was completed with a third group of questions focusing on informants' demographics and a confirmatory review of issues discussed.

\section{INSERT TABLE 1 AROUND HERE}

\section{Data Analysis}

Data analysis followed three steps. Interviews were first assigned a number, transcribed and inspected one by one. Information was afterwards grouped according to the research's themes. And finally, the analysis of interviews was performed taking into consideration the need to: (i) characterise active participation and interaction, (ii) identify focuses and levels of attentional behaviour, and (iii) identify meanings and levels of memorability. As the research themes had been identified prior to conducting the interviews, the analysis followed a deductive method.

Reliability and validity were considered during the research process and analysis of data. Both the interview script and interviewees' reports were clarified and discussed between the researchers as a reflection exercise and to critically judge the data obtained. Subsequently they performed the integration of respondents' reports with the themes and analysed them. The verbatim quotes here presented all derive from the interviews conducted and selection is based on the relevance of content to explore the themes. 


\section{RESULTS}

\section{Participants Profile}

Similar numbers of female (12) and male respondents (10) were interviewed with the majority between 31 and 50 years old and having higher status job, higher educational levels and qualifications (Table 2). Most were international tourists, visiting the park for the first time and word-of-mouth from friends and relatives was the most frequent source of information about Zoomarine. Interacting with the animals was the reason indicated by 18 informants for selecting this experience among other propositions offered by the park; living a unique or a one lifetime experience was the motive named by 14 participants and doing things and feeling strong sensations and emotions was the selection criterion for 10 respondents.

\section{INSERT TABLE 2 AROUND HERE}

\section{Structure of the Dolphin Emotions Experience}

The Dolphin Emotions Experience is designed to afford the participant close contact with dolphins. As such, it is planned to develop in several stages and for participants to achieve the peak of physical and emotional engagement during contact in the water. Information about the architecture of this experience was obtained from the team, though participants themselves were able to perceive its three-stage structure, which includes: the pre-experience phase, the core experience phase, and the postexperience phase.

\section{INSERT FIGURE 1 ABOUT HERE}

The pre-experience phase is sub-divided in three parts: the reception of participants, the preparation for the dolphin interaction, and an educational session. The first stage starts with the instructor joining the group at the meeting point and leading participants to the park's private area. They are made comfortable and the environment provides the context for an informal and relaxing first contact to occur with the instructor and other members of the travel party (including those swimming with dolphins and observers). Usually travel parties are composed of relatives (parents and children, spouses) and/or groups of friends. 
The second part consists of preparation for the dolphin interaction. The instructor informs participants about details of the venue and facilities, supplies them with the required equipment and tells them what to do. Though most communication is onedirection (from instructor to the group), interactions are informal and instructions conveyed in a friendly and enthusiastic tone. Stage three involves a 30 minute educational session, during which participants learn about dolphins (basic facts on species characteristics and anatomy, behaviours, curiosities), environmental issues (pollution and fishery practices, home recycling and benefits), and the specific behaviours to perform in the water. The session aims at conveying information and generating awareness of environmental problems, but also stimulates participants' engagement through lively and dynamic dialogue.

The second phase is the core experience, i.e. the interaction with the dolphins. After the lecture, participants are asked to go to the pool and join the trainer and the dolphins. In the water, they have physical contact with animals, execute planned behaviours under the instructor's and trainer's supervision, and are allowed the freedom to engage in friendly and close relationship with dolphins. The instructor stimulates participants to caress, touch, kiss and embrace them, so that emotions and positive feelings may emerge in harmony with sensations. The third phase is the post-experience. In the course of this phase, participants are allowed a pause for drink and a light meal during which they can get together in moments of socializing and relaxation. Interactions develop freely among the travel party, the instructor and other participants. As interaction with animals is completed, participants and observers engage in exchanges of stories, observations, and judgements.

\section{Active participation}

Participants were asked to identify and describe in their own words the activities they were involved in, how they felt about them and to evaluate their level of active participation. They discussed four different types of activities, each related to a particular mental state. These were socializing related to relaxation/expectation/recall; preparation related to enthusiasm; lecture attendance related to concentration, and dolphin interaction related to flow/absorption/immersion. As to the level of active participation perceived in the experience, the respondents considered it very high. 
Socializing describes the set of activities and related behaviours involving some kind of interplay between individuals during stage one of the pre-experience phase and the post-experience phase. Socializing includes having drinks and nibbles and engaging in informal talks with others and involved moments of casual, spontaneous conversation associated with feelings of relaxation.

Preparation activities were related to acquiring information about the venue facilities and use, instructions on swimming equipment, particular actions required to prevent harm to the dolphins during the interaction, or attendance to participants' special needs. Participants were excited:

"We felt very well oriented, which was important to deal with what was coming, i.e. the swimming experience with the dolphins. I felt we were all very excited." [female, aged 42]

The Dolphin Emotions Experience involves the visitor in active physical and mental participation. Visitors distinguished between watching a performance, on one side, and participating and interacting with the dolphin, on the other.

“This experience was not a show, you are not part of a show, you're actually doing something, participating, interacting.” [male, aged 48]

Active mental participation referred to interest, concentration and absorption/immersion. Such participation occurred when visitors were given a lecture on dolphins and marine life, but also when asking questions of the instructors. Some were cognitive, factual and 'cold' learning experiences:

"The lecture on the dolphins has been very important, I learned new facts". [female, aged 34]

Animal interaction involved active physical participation when visitors entered the water, swam with the dolphins, and created a more aroused state of mind.

"This experience is very interesting and absorbing, I was very talkative in the water." [female, aged 42] 
The interviews revealed that those stages involving mental and physical participation were the core of the experience and provided feelings of satisfied curiosity, learning, relaxation, fun, freedom and flow.

\section{Interaction}

Questions related to interactions during the experience focused on the subjects the participants interacted with, the type/nature of the interactions and their level of intensity in terms of frequency. In the Dolphin Emotions Experience, respondents identified the following groups: relatives and friends (travel party), other visitors, instructors, trainers and the dolphins. For most participants, interactions were perceived as high or very high.

Travel party: Interactions with the travel party were mentioned by many respondents and described as highly emotional and associated with strong positive feelings and emotions. In some cases, e.g. when children were part of the travel party, interactions between participants were seen as more important than interactions between participants and animals:

"More important than relating with the dolphins was being with my son and spouse.” [male, aged 47]

This is especially the case of parents who consider sharing the experience with their children moments of exceptional closeness and intimacy:

"It was a very intimate moment with my family and I learned new things about my son I hadn't realized. ” [male, aged 47]

"This was the first time I and my daughter had this experience and observing her relating with the dolphin was awesome!" [female, aged 30]

The reverse could also be found, when sons and/or daughters were participating in the experience accompanying their elderly parents. Emotionality is also prominent in respondents' own words:

"This experience was very intimate and personal. The motivation had to do with indulging my mother a long wished-for experience we were about to share." [male, aged 35] 
Instructor: Interactions with the instructors were also important in this experience, and though positive feelings are reported, most frequent descriptions relate to education and learning, on one hand, and sociability, on the other.

"This experience was not only about fun but also about education and learning, and he [the instructor] was very humorous but also informative." [female, aged 28]

"I felt free to ask as many questions as I wanted and that made feel good." [male, aged 20]

In fact, respondents seem to make a clear distinction between these two dimensions in the instructor's role, and this fact appeared to add meaningfulness and a sense of completeness to the experience.

"There was a lot of information and all processes were easy and well done. The monitor talked to all of us, she knew our names, she had fun with us, she made it all easy for us. From a service point of view, everything was perfect; the lecture we attended to was very important because I learned a lot of new facts.” [female, aged 35]

The instructor is the only staff member present throughout the experience, and the need to connect all participants, moments and stages demands from him or her the ability to set a positive tone, as well as providing information.

Trainer: Trainers are animal experts and most of their time is spent in close contact with the dolphins. During the Dolphin Emotions Experience, their role is performed exclusively in the pool and regularly lasts for about 30 minutes. Interactions with participants are only in the water, after the lecture. According to the informants, encounters with the trainers, unlike with the instructors, focused on educational content and appropriate behaviour towards the dolphins, and repeated accounts have been given on the trainer as a role model:

"He was always teaching us how to behave with the animals, how to make the most of the experience of being in the water with the dolphins." [male, aged 20] 
Their presence in the water, during interaction with animals, conveyed feelings of safety and comfort to participants because they were seen as being there to guide and align behaviours according to safety principles and requirements.

Other visitors: Interactions between participants, observers and other visitors are characterized by spontaneity. They may occur, or not, they can involve shallow conversations or, on the contrary, develop into more profound personal exchanges. Such encounters, conversations, and narratives, though allowed by the experience design, are not planned to happen in a certain way or indeed at all. Connections between visitors depend on contextual, circumstantial factors, such as the travel party including children or sharing the same condition, e.g. being pregnant.

In general terms, these interactions were reported as social, positive, experience improvers, some involving sharing of personal stories and life experiences. One respondent indicated that experiencing the same emotions and feelings as others was quite normal and expected:

"There was great excitement among all of us, we talked a lot concerning what we were about to do, as well as our common fears.” [female, aged 18]

Such perception appears to develop from awareness of group belonging and goal commonality, no matter how brief. Encounters with other visitors, though understood as of short duration, are not viewed as compromising experience meaningfulness or memorability; the opposite, in fact, seems to be true. One respondent claimed that:

“Though I may forget other people's faces, I won't forget the fact that they have been here with me having this same fantastic experience." [female, aged 35]

While another said:

"Being alone in this experience wouldn't have made any sense to me."

[female, aged 36]

Reports on interactions with other visitors (participants and observers) varied in terms of intensity and frequency. Some said they didn’t interact with anyone else except the instructor, while others reported they interacted with many other participants. They 
also revealed that there was awareness of the importance of being part of a group for positive experience outcome.

Lack of contacts between visitors was as a result of external, circumstantial rather than a lack of desire to socialize. People wanted to socialize but there were barriers. For instance, three respondents mentioned language barriers and how those barriers affected relations, and eventually prevented interactions from happening. Other accounts however highlighted intensity of interactions with other participants:

"I talked a lot with other participants, my interactions were very strong and intense." [male, aged 32]

In general, there were positive feelings group interaction in experiences involving challenge and novelty. The Dolphin Emotions Experience involved the unknown respondents commonly felt fear of failure; being part of a group was understood as a way to overcome those feelings. One interviewee stated that:

"Being part of a group of people made me confident in my capacity to achieve our goals” [male, aged 20],

Notions of communitas, connection, unitedness and experience intensification emerged as characteristic of interactions among participants, with human companionship leading to funny and meaningful moments. Respondents described interaction with the group of participants:

“This communion and sharing with others this unique, single moment...”[female, aged 35]

Another respondent stressed the fact that no matter how brief the encounter, they can generate feelings of connection:

“Even if you don't get to know people that well, you know what they're feeling, you sense the connection between them." [female, aged 51]

Dolphins: The Dolphin Emotions Experience provides an encounter with animals which are seen as friendly and attractive, almost like a house pet. Dolphins were 
compared to dogs, but also to humans, not only because of their marked anthropomorphic facial features (smiling mouth and expressive eyes), but also because of their behaviour. In this experience environment, dolphins are domesticated animals and respond to humans as any other domesticated species, i.e. through conditioning learning processes. This was ignored by respondents, who attributed their behaviours to a friendly nature.

Despite this, the interaction between human and animal engaged the sense and emotions in the highest degree, forming the basis of strong positive emotions and the substance of future memories:

"I was surprised with the taste of the salty water, the odour of fish, the noise made by the dolphins as they breathe, the freshness of the water they throw at you each time they inhaled, the kisses they give you, the sensation of touching their skin, so similar to smooth rubber. I felt tenderness towards those animals, all I wanted was to hug them, hold them tight."

[female, aged 20]

"The sensorial exploration of the dolphin, the touch of the skin, the sounds were great, caressing the dolphin was very emotional, it resembled a dog we meet in the street and feels like cuddling; these animals' intelligence is touching and captivating."

[male, aged 24]

Both the sensorial and the emotional dimensions contributed to a very positive appraisal of the experience, sometimes based on the perception of ultimate closeness with nature. Interactions with the dolphins are often referred to as "the reason why", the core, in other words, the peak experience. These moments of heightened sensitivity and emotionality have been described by respondents alternatively as immersion, absorption and flow:

"I was very relaxed and immersed in the experience." [female, aged 42]

"In the water, there was just me and the dolphin, I was completely absorbed and forgot about all the rest." [female, aged 36]

"When the dolphin approached me I forgot about everything, I felt my head was empty...”[male, aged 47] 


\section{Attention}

Attention has been described by respondents as focus or concentration. Participants have been asked to identify their focus, evaluate their level of attention during the experience and assess the influence of active participation and interaction on attention. Peak attention (very high levels) characterized, for the majority of respondents, the lecture time and the moment of interaction with the dolphins but there appear different meanings types of behaviour. Informants paid attention to different elements of the experience: animals, information, own behaviours and states of consciousness (thoughts, feelings, emotions), and other people (travel party, visitors, staff). The influence of active participation on attention was evaluated high to very high. As to the influence of interaction on attention, respondents evaluated it as high.

Animals: Dolphins are the core attraction of the experience and interaction with them is the expected benefit and focus of attention. Visitors were motivated by " $a$ long wished-for thing", "a one-time life experience"; spending invaluable time with very friendly, human-like animals. For others, the main motive was to afford this experience to relatives (children and/or elderly parents). But even for these participants

"being in the water interacting with these animals was a very intense thing..." [male, aged 61]

Reports on level of attention to dolphins varied from high to very high for most participants. Vivid and detailed descriptions were associated with feelings of surprise caused by the array of sensations:

"I was caught by surprise when I actually went into the water and touched; the salty water, the smell of fish, the noise of their breathing, their kisses and skin, so spongy and rubber-like.” [female, aged 25]

Information: refers to content disseminated in both formal (lecture) and informal (instructor/trainer conversations) contexts. In the Dolphin Emotions Experience, topics related to marine and mammal (dolphin) life and biology, and global environmental issues but a difference between those contexts emerged. The lecture was a moment of heightened attention related to the interest in the educational themes and anticipation of 
the upcoming performances in the water. Participants expressed concerns as to how would they respond to this challenge:

"It is a new experience, so it is important to learn something before it happens." [female, aged 20]

"If you're attending a lecture before going into the water and do things, you'll pay more attention to it because you're always thinking what will happen and how...” [male, aged 40]

Information was also received informally during time spent in the water with the trainers. Respondents revealed high level of attention to this content.

Participants: showed high awareness of the interactive character of this experience and expressed their engagement either in behavioural terms or in mental, psychological ones. Attention to subjective events, i.e. states of mind, and to own behaviours was perceived as high or very high. Several respondents mentioned feelings of happiness and joy and associated bodily responses, but also negative emotions linked to self-consciousness, such as anxiety and vulnerability.

Happiness and joy were explicitly noted:

"What I most attended to was just being there in the water feeling happy and smiling all the time." [female, aged 36]

Attention to negative emotions and feelings was equally expressed in straightforward terms. One respondent declared feeling vulnerable as a result of being left alone with the dolphin, isolated in the centre of the pool, away from others. These descriptions suggest there is a connection between participation in the experience and attention:

"I was very attentive to my own behaviour because I was the first of the group being asked to go to the centre of the pool with the dolphin.” [male, aged 20]

"Being an actor increased my attentive behaviour because the instructor taught us how to perform our part in the water." [female, aged 30] 
Instructors and trainers: Attention was paid to instructors and trainers due to their role of information disseminators and as role models for interaction, setting the rules of behaviour, assisting and monitoring participants and correcting them if necessary. Some respondents reported that instructors and trainers as capturing and maintaining attention. Their special knowledge and well trained skills were recalled in detail. One participant referred to the trainer's body movements and gestures as:

“...loaded with different and complex instructions, almost imperceptible signs... We could see those gestures only if we paid full attention to their hands." [male, aged 18]

The travel party, usually composed of spouses and/or children, was also a focus of high or very high attention. The behaviours and feelings (joy and enthusiasm) of others also captured and maintained attention:

"I was observing my daughter all the time, her behaviour and experience with the dolphin...”[female, aged 34]

Another stated:

"I was very attentive to the lecture but more to my son's behaviour, as he was addressing questions to the instructor." [male, aged 48]

Other participants and observers were a moderately important focus of attention, varying according to group dynamics, language barriers, and socializing motivations. Attention to other participants was often used to determine appropriate standards of behaviour:

"I observed the others, I learned from them and tried to replicate the same behaviours...”[female, aged 36]

\section{Memorability}

In general terms, the Dolphin Emotions Experience was considered highly memorable and both active participation and people interaction were considered strong influencers of memorability. However, the most memorable aspect of the experience was for all respondents' interaction with the dolphins. Interaction with animals was memorable for most participants and described as "unforgettable", "enduring", an 
“everlasting memory", and "I'll never forget”. On closer analysis, most vivid memories refer to tactile sensations and the particular emotional moments when participants were in the water. Indications of flow experience were found in relation with animal interaction, and this condition, as described by one respondent, was presented as explanation of enduring memory:

"During this interaction, I felt there was nothing else out there besides me and the dolphin, and this feeling I will always remember." [female, aged 46]

Active participation with dolphins was unanimously highly memorable. Some respondents referred to being actors and playing a role when imitating the trainers, and others referred the difference between seeing and doing, or, seeing the show and being part of it. A respondent declared that active participation:

“makes everything different, watching isn't enough, you just have to live it [the experience]...” [male, aged 48]

This viewpoint was shared by most participants interviewed. Others stressed that memorability was associated with the emotional intensity involved in active participation, which was invoked as a result of “doing things”:

"what contributes most to memorability of my experience is really the fact of being with the animals doing things with them" [male, aged 28]

As noted above, the presence of others is also perceived as meaningful and contributes to experience memorability. However, interactions with other participants showed more variation and its contribution to experience memorability reflects such variation. Some informants said that interacting was not particularly relevant while others considered that:

"if there were no other people to share these moments with, the experience wouldn't be so memorable..." [male, aged 20]

All participants found the overall experience highly memorable and common expressions of such appraisal were "unforgettable experience”, "I'll always remember 
this", "this experience will last in my memory”, “you know it will be memorable after living it”. Reasons were "a one-time [or unique] experience”, "a new experience”, “an extraordinary experience”, "a challenging experience”, or "an intimate and personal experience".

\section{Unplanned events}

Interview findings suggest that strong emotions, attention, and extreme memorability can also be associated with contacts in the experience environment outside the planned moment of interaction with the dolphins. Two examples may account for this claim. First, a respondent told about how having met another young woman has been a very intense part of the experience. This intensity, which she explained in terms of conversation (duration and issues covered) and pleasant feelings (informality, friendliness), was due to sharing the same language and common life contexts (both of them being recent mothers). As they spoke they talked about their life backgrounds, how it feels to be a mother, and all the changes that the condition brings to personal and professional life:

"It felt very good to talk like that, I was happy; I found her [the woman interlocutor] very pleasant to talk to, we got excited talking about our children and professions... how hard it is to cope with every kind of demands."

[female, aged 34]

Another respondent was sensitive to what was felt as a special situation involving another participant with a terminal illness. This individual was perceived as partaking in the experience as a last opportunity to satisfy a wish and experience happiness. The respondent reported that observing that person was:

"very touching, emotional, her presence elevated everyone's experience in the group”. [male, aged 20]

Thus the presence of other humans is noticed and meaningful for individuals even though interactions with the animals were the core attraction. The extraordinary, outside the designed experience, can contribute to an overall high appraisal of the experience. 


\section{Experience Summary}

The Dolphin Emotions Experience comprises three phases - pre-experience, core experience, and post-experience, and each phase has been analysed in terms of active participation, interactions occurred, attentional focuses, and memorability. Table 5 summarizes it based on the researcher's conversations with staff, researchers' observations and information collected from interviews and it shows the variety of activities which participants have been engaged in, and significant people in participants' interactions in the different phases of the experience. For example, during the delivery of the lecture, core interaction developed between the participant and the instructor. As can be observed in the table, phase two is characterized by high intensity interaction bringing people closer together.

Participants' reports also show variation in attention, and attentional focus during the stages of the experience. The travel party and the instructor received attention throughout the experience. In the pool, the dolphin is the main focus of attention. Participants' attention returns to the travel party in the post-experience phase, although the dolphin remains the subject of vivid narratives exchanged between family members and/or friends. The table also shows changes in memorability through the different stages. Memorability is primarily related to sociability in the first stage of the pre-experience phase and the post-experience phase; and in the stages of preparation and lecture attendance (also during the pre-experience phase), it is concerned concurrently with sociability and learning contents. Feelings, emotions, and sensations comprise the main substance of the core experience.

\section{INSERT TABLE 5 AROUND HERE}

\section{DISCUSSION AND CONCLUSION}

This research supports the argument that co-creation involves tourists' active participation and interaction in experiences (Rihova et al., 2014; Tan et al., 2013; Volo, 2009), and is a particular way of living and performing the experience. Co-creation centres on the tourist and understanding it requires exploring the psychological effects of the tourism experience (Larsen, 2007). Active participation, either in physical or mental terms (Bertella, 2014; Minkiewicz et al., 2013; Prebensen \& Foss, 2011), has been found highly relevant for tourists because it focuses attention on their experience, leading to higher levels of memorability. This study supports findings that link active participation 
and interactivity to attention (Hunter, 1994; Kuhl \& Chun, 2014) and also results from educational theory, cognitive psychology and neuroscience connecting attention and memorability (Almarode \& Miller, 2013; Chun \& Turk-Browne, 2007; Fahy, 2004; Hunter, 1994; Snell, 1999). Peaks of attention were found in two types of activity: cognitive activity, involving learning, information, and knowledge acquisition (Kolb, 1984), and physical activity, requiring body movements, as with swimming. Tourists were cognitively active mostly during the lecture session, covertly, e.g. when listening to the instructor, and overtly when asking a question. Physical activity was specific to the moment of interaction with the dolphins. These two dimensions, mental and physical activity, were reported to contribute to experience attention and memorability. From a managerial point of view, these findings may stimulate organizations to design experiences that involve learning opportunities in a leisure-based context so that tourists may feel they are acquiring new knowledge and developing new skills in a friendly, noncompromising manner. In fact, the results suggest managers need to help in creating the right blend of educational and entertainment values (Hertzman, Anderson \& Rowley, 2008).

This study found that active participation in experience activities and interactions with others are significant contributors to enhanced attention. Attention was revealed by these participants as an effect of co-creation and an influencer of memorability. In turn, memorability was perceived an outcome of co-creation experiences (Bertella, 2014) and a very important issue to these visitors as it links to the meaningfulness of the experience (Minkiewicz et al., 2013). Recollection is a dimension of experiences and memorability may be facilitated by those that are felt as an "once-in-a-lifetime experience” (Tung \& Ritchie, 2011a). However the relationship between co-creation of experiences and memorability needs to be further analysed from a psychological perspective that allows viewing the dynamic presence and influence of psychological processes in this experience outcome.

In this study, attention is one such a psychological process. Informants equated attention with focus, and concentration. This fits into generally accepted definitions of selective attention and sustained attention (Driver, 2001; Oken et al., 2010). Peaks of attention in this experience were described as related to the novelty and out-of-theordinariness of the encounter, such as swimming and touching the dolphins, which may indicate that respondents were mindful towards key moments of the experience 
(Moscardo, 1996; Tung \& Ritchie, 2011a). Novelty has been linked to tourists' motivation for travel (Andersson, 2007; Pearce \& Kang, 2009; Quan \& Wang, 2004; Thompson, 2008), and in their description of commercial experiences, Poulsson and Kale (2004) considered novelty (and surprise) a necessary ingredient of experiences and an experience-enhancer (Prebensen, Woo, \& Uysal, 2013b). Additionally, qualitative research concluded that novelty influences the memorability of the co-creation experience (Bertella, 2014) and a quantitative study revealed that novelty is a dimension of memorable experiences (Kim et al., 2012). As focus and concentration are connected to novelty, managers are challenged to constantly align experiences with tourists' expectations towards novelty.

Another interesting finding of this study is the emphasis respondents put on close and intense human relationships, in terms of frequency (much, a lot) but also affect (fun, enjoyable, pleasant, touching), showing that far from secondary elements of the experience environment, other people are in fact at the core of the co-creation experience with consequences for its memorability. This supports prior research conducted about the importance of others in the experience environment (Arnould \& Price, 1993; Bharwani \& Jauhari, 2013; Minkiewicz et al., 2013; Rihova et al., 2014; Rihova et al., 2013; Wikstrom, 2008). This research has shown that human interactions and interdependence are important and high in co-creation experiences (Arnould \& Price, 1993) since active participation requires harnessing of personal resources (intellectual, physical), goal setting and willingness to overcome challenges, and success in doing so depends on the intervention of skilled people (such as the instructor or trainers) or the motivational drive of other people going through the same experience (Ihamäki, 2012; Rihova et al., 2013).

Engaging in informal and ephemeral conversations, though positive for most participants, was not seen as relevant for experience memorability as the emotional intensity they carried. In this sense, socializing is a means to achieve emotional states related to communion and sense of bonding (Arnould \& Price, 2013). Grouping is an element of the design of this co-creation experience, and participants understood it as an opportunity for interacting. Encounters generated positive and strong emotions. Arnould and Price (1993) reported participants in the river raft trip perceived the guides not as service providers but as friends, thus concluding that a sense of communitas develops not only between participants but also with the company's staff. This study indicates interaction with people in experiential consumption involves this emotional 
connectedness (Bharwani \& Jauhari, 2013). Therefore connectedness, bonding, communion are strong drivers of co-creation experiences as they connect the tourist with relatives, friends and others. These findings indicate that staff members can contribute to opportunities for greater interaction between participants and to their feelings and emotions through storytelling and pleasurable communication (Mathisen, 2013). Interactive communication skills therefore are recommended as dimensions to be further improved in the context of co-creation experiences.

The analysis also highlights the distinction between wild events and interactions (Scott et al., 2009), on one side, and normal, expected, planned events and interactions, on the other. Co-creation experiences accommodate high level of variability (Prahalad \& Ramaswamy, 2004) that may lead to a certain degree of unexpectedness and emergence of extemporaneous or unexpected events or situations. Such informal and spontaneous events are capable of becoming memorable as much as the main event (Arnould \& Price, 1993; Morgan, 2006; Tung \& Ritchie, 2011a, 2011b). The memorability of an experience can be related to positive surprise and can account for manifestation of emotion, interest, excitement (Mossberg, 2008; Tung \& Ritchie, 2011a) and contextual-prompted conversation (Mathisen, 2013). Lasting and impressive experiences have been reported during interactions of tourists while on a guided tour with residents and associated with the experiences' unexpectedness and spontaneity (Jonasson \& Scherle, 2012). Though variability and unpredictability are characteristics long known to service managers and marketers (Hoffman \& Bateson, 2011), these are inherent to experiences highly dependent on contextual variables; thus co-creation experiences require commitment to constantly observe the balance between accommodation and reduction of variability and unpredictability, as well as to positive surprise.

In this study, tourists described the tourism experience as mediated by attention (Ooi, 2010). In experiential contexts, such as co-creation environments, attention can be directed to guides, instructors or trainers of different sorts and they all play a role in facilitating engagement by immersing tourists in the experience (Carù \& Cova, 2007; Mossberg, 2008). On the other hand, as co-creation experiences are favourable contexts to development of skills, interactions between these facilitating mediators and tourists are increasingly decisive because it is during these interactions that attention is guided to the stimuli. This suggests that research on the role of experience mediators in co-creation experiences deserves further development. 
Another finding of this study relates to the importance of the sensory dimension in co-creation experiences. The experience economy paradigm (Pine \& Gilmore, 1999) and the experiential marketing approach have already called attention to the importance of the senses in consumer experience (Gentile, Milano, \& Noci, 2007; Holbrook \& Hirschman, 1982; Schmitt, 1999). Agapito, Mendes, and Valle (2013) have reviewed literature on the senses, discussing the relevance of the theme in the context of tourism experiences and highlighting the relevance of sensescapes. This multi-sensoriality leaves a permanent imprint on memory. Ballantyne, Packer, and Sutherland (2011, p. 773) reported vivid memories based on multi-sensory impressions and also that "to be physically close to the animals (...) made the experience novel or remarkable”. The same is found in the Dolphin Emotions Experience. Nevertheless, further investigation of multi-sensoriality on attentional behaviours or memorability of co-creation tourism experiences need not be animal or nature-based since many other activities in contemporary creative tourism require the tourist's use of body and physical engagement. Artistic performances (dance, music), gastronomy or crafts are experiential contexts that allow detailing of the relationship between active participation, senses, attention and memorability.

The study has limitations in terms of scope and methodology that further research may address. The first is that only one co-creation experience was considered in this study. Thus further study could improve on broadening the scope of analysis of cocreation experience, attention and memorability to other experience modalities, e.g. involving sports and adventure or learning and skills development in language or arts and crafts. Another limitation is its narrow scope, focusing on attention and memorability. Attention is a process implicated in the perceptual functions of the individual, needed for stimulus selection and interpretation but other related processes and factors should be taken into account to refine our knowledge of motivations and their role on attention. The qualitative methods used here generate insightful conclusions about the topic analysed but studies using these category of methods lack generalizability and face issues of replicability (Finn et al, 2000). This qualitative study probed the use of scales and subsequent research should test their application adopting a quantitative methodology.

Both literature review and the study findings reveal opportunities for future research, especially empirical studies about on-site co-creation experiences and the 
psychological processes involved. More particularly, research is required on a) identification and description of psychological processes (perceptual, cognitive, and affective) involved in co-creation tourism experiences that may influence memorability; b) measurement of the influence of active participation and interaction, as dimensions of co-creation, on focused attention and other psychological processes occurring during onsite experiences; c) analysis of the experience mediators' role and the extent to which they are important as attention leaders in co-creation experiences; d) investigation of the impact of the sensory dimension of co-creation experiences on memorability, but also exploration of the multiple senses as attention capturers and maintainers during these experiences; e) examination of the degree of spontaneity and unexpectedness in cocreation experiences and relevance as memorability enhancers; f) description and discussion of participants' interactions and social spheres in on-site co-creation experiences.

For tourism organizations, these research findings are of practical use when designing an experience. Effective experience design and management requires the tourist's active participation. Adopting a mix of entertainment and learning dimensions in a socially rich environment may enhance an experience by focusing attention and may lead to better knowledge acquisition and emotion elicitation. Design of the experience should take into account the individuals' sensitivity to the level of physical, intellectual or social challenge involved in activities.

This research has explored psychological reactions to a designed participative and interactive experience. The study findings support the importance of active participation and interaction in co-creation and highlights the importance of attention in co-creation tourism experiences, therefore affording grounds for further exploring inclusion of attention stimuli in the design of memorable tourism experiences. Elaborating from Ooi’s (2003, 2010) reflections on attention in the context of tourism, the case study explored empirically this theme and results indicate tourists are aware of heightened attention when actively engaged and interacting with other subjects. 
Figure 1: Experience Stages

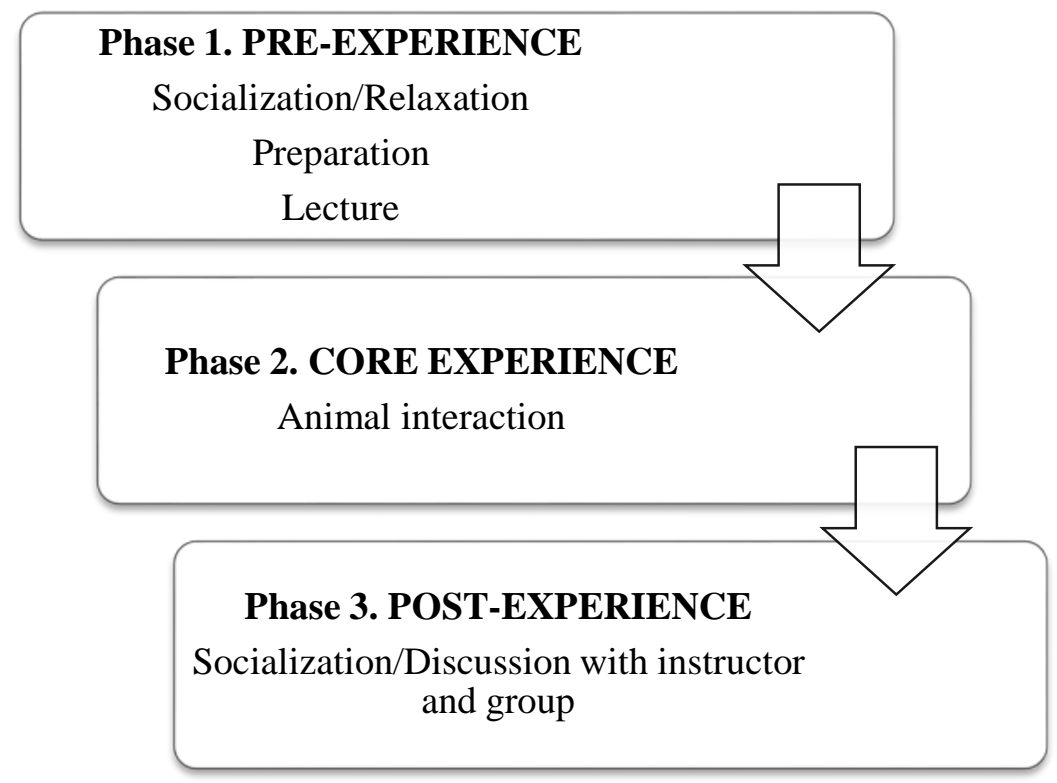

Table 1: Themes, questions and focuses used in the interviews

\begin{tabular}{|c|c|c|c|}
\hline Themes & Questions (examples) & Focus & Literature sources \\
\hline $\begin{array}{l}\text { Active } \\
\text { participation }\end{array}$ & $\begin{array}{l}\text { Could you describe what did } \\
\text { you do/were asked to do? } \\
\text { Could you tell which did you } \\
\text { find your most important } \\
\text { tasks/behaviours/ } \\
\text { performances? } \\
\text { Could you tell what did it } \\
\text { mean to you to participate in } \\
\text { this experience? }\end{array}$ & $\begin{array}{l}\Rightarrow \text { own performance, type } \\
\text { of activity, contribution to } \\
\text { accomplishment of the } \\
\text { overall experience } \\
\Rightarrow \text { perception of importance } \\
\text { of own performance }\end{array}$ & $\begin{array}{l}\text { Wikström (2008): } \\
\text { own activity } \\
\text { Mathisen (2013): } \\
\text { tourist performance }\end{array}$ \\
\hline Interaction & $\begin{array}{l}\text { - Did you find this experience } \\
\text { important as an opportunity to } \\
\text { socialize with people? } \\
\text { - Could you tell who did you } \\
\text { most relate to during the } \\
\text { experience? } \\
\text { - How would you describe } \\
\text { those interactions and most } \\
\text { influential aspects? }\end{array}$ & $\begin{array}{l}\Rightarrow \text { subjects involved in } \\
\text { interactions } \\
\Rightarrow \text { importance of social } \\
\text { interactions } \\
\Rightarrow \text { nature of interactions }\end{array}$ & $\begin{array}{l}\text { Mathisen (2013): } \\
\text { social bonding, group } \\
\text { interaction, like- } \\
\text { minded individuals }\end{array}$ \\
\hline Attention & $\begin{array}{l}\text { - Could you tell what captured } \\
\text { and kept your attention in a } \\
\text { higher degree during this } \\
\text { experience? Which aspects or } \\
\text { parts of it did you attend to } \\
\text { most? } \\
\text { Could you tell why you were } \\
\text { particularly attentive in those } \\
\text { moments? } \\
\text { Do you find being a } \\
\text { participant in the experience } \\
\text { and socializing with others } \\
\text { influenced in any degree the } \\
\text { attention you paid to events? }\end{array}$ & $\begin{array}{l}\Rightarrow \text { focuses of attention } \\
\Rightarrow \text { perception of attentional } \\
\text { behaviour } \\
\Rightarrow \text { reasons of attentional } \\
\text { behaviour } \\
\Rightarrow \text { influence of active } \\
\text { participation and interaction } \\
\text { on attention }\end{array}$ & $\begin{array}{l}\text { Bitgood (2010): } \\
\text { focused and engaged } \\
\text { attention } \\
\text { Patterson \& } \\
\begin{array}{lr}\text { (1988): } & \text { Bitgood } \\
\text { participation active } & \text { and } \\
\text { attention }\end{array}\end{array}$ \\
\hline
\end{tabular}




\begin{tabular}{|c|c|c|c|}
\hline & $\begin{array}{l}\text { - Could you tell me more about } \\
\text { it? }\end{array}$ & & \\
\hline Memorability & $\begin{array}{l}\text { - What did this experience } \\
\text { mean to you, do you find it } \\
\text { memorable? } \\
\text { - Could you explain why? } \\
\text { - Could you detail most } \\
\text { impressive moments or } \\
\text { aspects of this experience? } \\
\text { - Do you find being a } \\
\text { participant in the experience } \\
\text { and socializing with others } \\
\text { influenced in any degree how } \\
\text { memorable the experience is? } \\
\text { - Could you tell me more about } \\
\text { it? }\end{array}$ & $\begin{array}{l}\Rightarrow \text { perception of vividness } \\
\text { and likelihood of long term } \\
\text { recollection } \\
\Rightarrow \text { memorable dimensions } \\
\text { of the experience } \\
\Rightarrow \text { influence of active } \\
\text { participation and interaction } \\
\text { on the memorability of the } \\
\text { experience }\end{array}$ & $\begin{array}{l}\text { Tung \& Ritchie } \\
\text { (2011a) and Kim, } \\
\text { Ritchie \& } \\
\text { McCormick (2012): } \\
\text { memorable } \\
\text { experiences } \\
\text { Reisberg, Heuer, } \\
\text { McLean \& } \\
\text { O’Shaughnessy } \\
\text { (1998): memory } \\
\text { vividness }\end{array}$ \\
\hline
\end{tabular}

Table 2. Participants' profile

\begin{tabular}{|c|c|c|c|c|c|c|}
\hline Gender & $\bar{F}$ & $\bar{M}$ & & & & \\
\hline $\mathrm{N}=22$ & 12 & 10 & & & & \\
\hline Age & $18-20$ & $21-30$ & $31-40$ & 41-50 & $51-60$ & $61-70$ \\
\hline $\mathrm{N}=22$ & 1 & 5 & 7 & 7 & 1 & 1 \\
\hline Occupation & $\begin{array}{l}\text { Senior officials } \\
\text { \& managers }\end{array}$ & Professionals & Technicians & Clerks & $\begin{array}{c}\text { Armed } \\
\text { forces }\end{array}$ & $\begin{array}{c}\text { Students/ } \\
\text { retired }\end{array}$ \\
\hline $\mathrm{N}=22$ & 5 & 3 & 8 & 4 & 1 & 1 \\
\hline Education & Basic education & $\begin{array}{l}\text { Secondary } \\
\text { education }\end{array}$ & $\begin{array}{c}\text { Higher } \\
\text { education }\end{array}$ & & & \\
\hline $\mathrm{N}=22$ & 1 & 6 & 15 & & & \\
\hline Nationality & National & International & & & & \\
\hline $\mathrm{N}=22$ & 6 & 16 & & & & \\
\hline
\end{tabular}

Table 3: Prevalent experience mental states during the experience phases

\begin{tabular}{|c|c|}
\hline $\begin{array}{c}\text { Mental states (feelings, emotions, } \\
\text { thoughts) }\end{array}$ & Activities and behaviours \\
\hline Relaxation/Expectation & $\begin{array}{l}\text { Phase 1: Socializing welcoming reception, coffee break, } \\
\text { conversations and group meetings }\end{array}$ \\
\hline Enthusiasm/Arousal & $\begin{array}{c}\text { Phase 1: Preparation changing clothes, instructions for } \\
\text { equipment use, particular needs }\end{array}$ \\
\hline Concentration/Focus & $\begin{array}{l}\text { Phase 1: Lecture attendance } \\
\text { observing, listening, asking questions, acquiring } \\
\text { information and knowledge }\end{array}$ \\
\hline Flow/Absorption/Immersion & $\begin{array}{l}\text { Phase 2: Dolphin interaction } \\
\text { swimming, playing, training, kissing, caressing, cuddling }\end{array}$ \\
\hline Relaxation/Recall & $\begin{array}{c}\text { Phase 3: Socializing } \\
\text { coffee break, conversations and group meetings, souvenirs }\end{array}$ \\
\hline
\end{tabular}


Table 4: Participants' evaluations of experience themes

\begin{tabular}{|c|c|c|c|c|c|c|c|c|c|c|}
\hline & \multicolumn{10}{|c|}{ Respondents' evaluations } \\
\hline & 1 & 2 & 3 & 4 & 5 & 6 & 7 & 8 & 9 & $\overline{10}$ \\
\hline Themes & \multicolumn{7}{|c|}{ Very low } & \multicolumn{3}{|c|}{ Very high } \\
\hline Active participation & 0 & 0 & 0 & 0 & 0 & 0 & 3 & 5 & 6 & 8 \\
\hline Interaction & 0 & 0 & 1 & 0 & 4 & 0 & 3 & 5 & 3 & 6 \\
\hline Attention & 0 & 0 & 0 & 0 & 0 & 0 & 1 & 2 & 10 & 9 \\
\hline Memorability & 0 & 0 & 0 & 0 & 0 & 0 & 4 & 5 & 2 & 11 \\
\hline $\begin{array}{l}\text { Importance of active participation } \\
\text { to attention }\end{array}$ & 0 & 0 & 0 & 0 & 0 & 0 & 1 & 7 & 8 & 6 \\
\hline $\begin{array}{l}\text { Importance of active participation } \\
\text { to memorability }\end{array}$ & 0 & 0 & 0 & 0 & 0 & 0 & 2 & 5 & 4 & 11 \\
\hline $\begin{array}{l}\text { Importance of interaction to } \\
\text { attention }\end{array}$ & 0 & 0 & 0 & 0 & 5 & 0 & 5 & 6 & 2 & 4 \\
\hline $\begin{array}{l}\text { Importance of interaction to } \\
\text { memorability }\end{array}$ & 0 & 0 & 2 & 0 & 2 & 1 & 3 & 4 & 3 & 7 \\
\hline
\end{tabular}

Table 5: Summary of stages of the Dolphin Emotions Experience

\section{EXPERIENCE STAGES}

\begin{tabular}{|c|c|c|c|c|c|}
\hline & \multicolumn{3}{|c|}{ Pre-experience } & \multirow{2}{*}{$\begin{array}{c}\text { Core } \\
\text { experience } \\
\text { Performance } \\
\text { of tasks and } \\
\text { behaviours in } \\
\text { the water }\end{array}$} & \multirow{2}{*}{$\begin{array}{c}\text { Post- } \\
\text { experience } \\
\text { Socializing and } \\
\text { relaxation }\end{array}$} \\
\hline & $\begin{array}{c}\text { Socializing } \\
\text { and } \\
\text { relaxation }\end{array}$ & $\begin{array}{c}\text { Preparation } \\
\text { for } \\
\text { interaction } \\
\text { with the } \\
\text { dolphins }\end{array}$ & $\begin{array}{c}\text { Lecture } \\
\text { attendance }\end{array}$ & & \\
\hline Activities & $\begin{array}{l}\text { Light meals, } \\
\text { beverages, } \\
\text { conversations } \\
\text { and group } \\
\text { meetings }\end{array}$ & $\begin{array}{l}\text { Changing } \\
\text { clothes, } \\
\text { instructions } \\
\text { for equipment } \\
\text { use, particular } \\
\text { needs }\end{array}$ & $\begin{array}{l}\text { Group } \\
\text { meeting with } \\
\text { the } \\
\text { instructor, } \\
\text { audio-visual } \\
\text { materials }\end{array}$ & $\begin{array}{l}\text { Swimming, } \\
\text { playing, } \\
\text { training, } \\
\text { kissing } \\
\text { caressing/cudd } \\
\text { ling }\end{array}$ & $\begin{array}{l}\text { Light meals, } \\
\text { beverages, } \\
\text { conversations } \\
\text { and group } \\
\text { meetings }\end{array}$ \\
\hline Interactions & Travel party & $\begin{array}{l}\text { Instructor and } \\
\text { Travel party }\end{array}$ & Instructor & $\begin{array}{l}\text { The Dolphin, } \\
\text { the trainer, the } \\
\text { instructor, the } \\
\text { travel party }\end{array}$ & Travel party \\
\hline Attention & Travel party & The instructor & $\begin{array}{l}\text { The } \\
\text { instructor }\end{array}$ & $\begin{array}{l}\text { The dolphin, } \\
\text { myself, } \\
\text { trainer, travel } \\
\text { party }\end{array}$ & Travel party \\
\hline Memorability & $\begin{array}{l}\text { Sociable } \\
\text { (experience } \\
\text { antecipation) }\end{array}$ & $\begin{array}{l}\text { Educational } \\
\text { and sociable } \\
\text { (informative } \\
\text { and friendly) }\end{array}$ & $\begin{array}{l}\text { Educational } \\
\text { and sociable } \\
\text { (informative } \\
\text { and friendly) }\end{array}$ & $\begin{array}{l}\text { Emotional } \\
\text { (strong very } \\
\text { positive } \\
\text { feelings and } \\
\text { emotions) and } \\
\text { physical } \\
\text { (sensations) }\end{array}$ & $\begin{array}{l}\text { Sociable } \\
\text { (positive, } \\
\text { friendly and } \\
\text { pleasant sharing } \\
\text { of past and } \\
\text { present life } \\
\text { experiences) }\end{array}$ \\
\hline
\end{tabular}




\section{REFERENCES}

Agapito, D., Mendes, J., \& Valle, P. (2013). Exploring the conceptualization of the sensory dimension of tourist experiences. Journal of Destination Marketing and Management, 2(2), 62-73. doi:10.1016/j.jdmm.2013.03.001

Aho, S. K. (2001). Towards a general theory of touristic experiences. Tourism Review, 56(3-4), 33-37.

Almarode, J., \& Miller, A. M. (2013). Captivate, activate and invigorate the student brain in science and math. London: Sage Publications.

Andersson, T. D. (2007). The tourist in the experience economy. Scandinavian Journal of Hospitality and Tourism, 7(1), 46-58. doi:10.1080/15022250701224035

Andrades, L., \& Dimanche, F. (2014). Co-creation of experience value: A tourist behaviour approach. In M. Chen, J., Uysal (Ed.), Creating experience value in tourism (pp. 95-112). London: CABI. doi:10.1079/9781780643489.0095

Arnould, E. J., \& Price, L. L. (1993). River magic: Extraordinary experience and the extended service encounter. Journal of Consumer Research, 20, 24-45.

Aron, A., Melinat, E., Aron, E. N., \& Vallone, R. D. (1997). The experimental generation of interpersonal closeness: A procedure and some preliminary findings. Personality and Social Psychology Bulletin, 23(4), 363-377.

Azevedo, A. (2009). Designing unique and memorable experiences: The unexpected surprise factor. Actas do III Congresso Internacional de Turismo de Leiria e Oeste, Escola Superior de Turismo e Tecnologia do Mar (ESTM/IPL), Peniche, 25 e 26 Novembro.

Ballantyne, R., Packer, J., \& Sutherland, L. A. (2011). Visitors' memories of wildlife tourism: Implications for the design of powerful interpretive experiences. Tourism Management, 32(4), 770-779. doi:10.1016/j.tourman.2010.06.012

Bandura, A. (1989). Social cognitive theory. Annals of Child Development, 6, 1-60.

Bertella, G. (2014). The co-creation of animal-based tourism experience. Tourism Recreation Research, 39(1), 115-125.

Bharwani, S., \& Jauhari, V. (2013). An exploratory study of competencies required to cocreate memorable customer experiences in the hospitality industry. International Journal of Contemporary Hospitality Management, 25(6), 823-843. doi:10.1108/IJCHM-05-2012-0065 
Binkhorst, E., \& Den Dekker, T. (2009). Agenda for co-creation tourism experience Research. Journal of Hospitality Marketing and Management, 18(2), 311-327. doi:10.1080/19368620802594193

Bitgood, S. (2010). An attention-value model of museum visitors. Center for the Advancement of Informal Science Education. Retrieved from http://caise.insci.org/uploads/docs/VSA_Bitgood.pdf-

Braun-LaTour, K. A., Grinley, M. J., Loftus, E. F. (2006). Tourist memory distortion. Journal of Travel Research, 44, 360-367.

Brooks, H. (1996). The problem of attention management in innovation for sustainability. Technological Forecasting and Social Change, 53(1), 21-26. doi:10.1016/00401625(96)00054-6

Brunner-Sperdin, A., Peters, M., \& Strobl, A. (2012). It is all about the emotional state: managing tourists' experiences. International Journal of Hospitality Management, 31(1), 23-30. doi:10.1016/j.ijhm.2011.03.004

Carbone, L. P., \& Haeckel, S. H. (1994). Engineering customer experiences. Marketing Management, 3(3), 8-19.

Carù, A., \& Cova, B. (2007). Consuming experience. Abingdon: Routledge.

Cary, S. H. (2004). The tourist moment. Annals of Tourism Research, 31(1), 61-77. doi:10.1016/j.annals.2003.03.001

Cho, T. S., \& Hambrick, D. C. (2006). Attention as the mediator between top management team characteristics and strategic change: the case of airline deregulation. Organization Science, 17(4), 453-469. doi:10.1287/orsc.1060.0192

Clark, J. J. (1997). Attention. Retrieved from http://wwwpsych.stanford.edu/ ashas/Cognition\%20Textbook/chapter3.pdf

Csikszentmihalyi, M. (1975). Beyond boredom and anxiety. San Francisco, CA: JosseyBass.

Cutler, S. Q., \& Carmichael, B. A. (2010). The dimensions of the tourist experience. In M. Morgan, P. Lugosi, \& J. R. B. Ritchie (Eds.), The tourism and leisure experience: Consumer and managerial perspectives (pp. 3-26). Bristol: Channel View Publications.

Dalton, R. Lynch, P. \& Lally, A-M. (2009). Towards an understanding of experience concept development in tourism service design. EuroCHRie, 22-24 October, Helsinki, Finland.

Davenport, T. H., \& Beck, J. C. (2000). Getting the attention you need. Harvard Business Review, (September-October), 118-126. 
Dayan, P., Kakade, S., \& Montague, P.R. (2000). Learning and selective attention. Nature Neuroscience, 3, 1218-1223.

De Jager, A. K. A. (2009b). Co-creation as a strategic element of tourism destination competitiveness. In 3rd advances in tourism marketing conference: Marketing innovations for sustainable destinations: operations, interactions, experiences. Bournemouth: Bournemouth University.

De Rojas, C., \& Camarero, C. (2008). Visitors' experience, mood and satisfaction in a heritage context: Evidence from an interpretation center. Tourism Management, 29(3), 525-537. doi:10.1016/j.tourman.2007.06.004

Dijksterhuis, A., \& Aarts, H. (2010). Goals, attention, and (un)consciousness. Annual Review of Psychology, 61, 467-90. doi:10.1146/annurev.psych.093008.100445

Dong, P., \& Siu, N. Y. M. (2013). Servicescape elements, customer predispositions and service experience: The case of theme park visitors (2013). Tourism Management, 36, 541-551. doi: 10.1016/j.tourman.2012.09.004

Driver, J. (2001). A selective review of selective attention research from the past century. British Journal of Psychology, 92, 53-78. doi:10.1348/000712601162103

Edensor, T. (2000). Tourists as performers. Annals of Tourism Research, 27(2), 322-344.

Ek, R., Larsen, J., \& Hornskov, S. B. (2012). A dynamic framework of tourist experiences: Space-time and performances in the experience economy. Scandinavian Journal of Hospitality and Tourism, (November), 37-41.

Fahy, P. J. (2004). Media characteristics and online learning technology. In F. Anderson, T., Elloumi (Ed.), Theory and practice of online learning (pp. 137-172). Athabasca University. Retrieved from cde.athabascau.ca/online_books

Falkinger, J. (2007). Attention economies. Journal of Economic Theory, 133, 266-294.

Ferdinand, N., \& Williams, N., L. (2010). Tourism memorabilia and the tourism experience. In Morgan, M., Lugosi, P., \& Ritchie, J. R. B. (Eds.), The tourism and leisure experience: Consumer and managerial perspectives (pp. 202-217). Bristol: Channel View Publications.

Finn, M., Elliot-White, M., \& Walton, M. (2000). Tourism and leisure research methods: Data collection, analysis and interpretation. Harlow: Pearson Education Ltd.

Gentile, C., Milano, P., \& Noci, G. (2007). How to sustain the customer experience: An overview of experience components that co-create value with the customer. European Management Journal, 25(5), 395-410. doi:10.1016/j.emj.2007.08.005

Gibbs, D, \& Ritchie, C. (2010). Theatre in restaurants: Constructing the experience. In Morgan, M., Lugosi, P., \& Ritchie, J. R. B. (Eds.), The tourism and leisure experience: Consumer and managerial perspectives (pp. 182-201). Bristol: Channel View Publications. 
Hertzman, E., Anderson, D., \& Rowley, S. (2008). Edutainment heritage tourist attractions: A portrait of visitors' experiences at Storyeum. Museum Management and Curatorship, 23(2), 155-175. doi:10.1080/09647770802012227

Hoffman, A. J., \& Ocasio, W. (2001). Not all events are attended equally: Toward a middle-range theory of industry attention to external events. Organization Science, 12(4), 414-434. http://dx.doi.org/10.1287/orsc.12.4.414.10639

Hoffman, K. D., \& Bateson, J. E. G. (2011). Services Marketing: Concepts, Strategies \& Cases, Mason, OH: Cengage Learning

Holbrook, M. B., \& Hirschman, E. C. (1982). The experiential aspects of consumption: Consumer fantasies, feelings, and fun. Journal of Consumer Research, 9 (September), 132-141.

Huberman, B. A., \& Wu, F. (2008). The economics of attention: Maximizing user value in information-rich environments. Advances in Complex Systems, 11(4), 487-496.

Hunter, M. (1994). Enhancing teaching. New York, NY: Macmillan College Publishing.

Ihamäki, P. (2012). Geocachers: The creative tourism experience. Journal of Hospitality and Tourism Technology, 3(3), 152-175. doi:10.1108/17579881211264468

Jennings, G. R. (2005). Interviewing: A focus on qualitative techniques. In C. Ritchie, B. W., Burns, P., \& C. Palmer, (Eds.), Tourism research methods, integrating theory with practice (pp. 99-118). Wallingford: CABI Publishing.

Jonasson, M., \& Scherle, N. (2012). Performing co-produced guided tours. Scandinavian Journal of Hospitality and Tourism, 12(1), 55-73.

Kim, J.-H. (2010). Determining the factors affecting the memorable nature of travel experiences. Journal of Travel \& Tourism Marketing, 27(8), 780-796.

Kim, J.-H., Ritchie, J. R., \& McCormick, B. (2012). Development of a scale to measure memorable tourist experiences. Journal of Travel Research, 51(1), 12-25.

Kolb, D. A. (1984). Experiential learning: Experience as the source of learning and development. New Jersey, NJ: Prentice-Hall.

Kreziak, D., \& Frochot, I. (2011). Co-construction de l'expérience touristique. Les stratégies des touristes en stations de sport d'hiver [Co-constructing tourism experience: The strategies developed by tourists in winter sports' resorts]. Décisions Marketing, 64, 23-34.

Kuhl, B. A., Chun, M. M. (2014). Memory and attention. In A. C. Nobre \& S. Kastner (Eds.), The Oxford handbook of attention (pp. 806-836). Oxford: Oxford University Press.

Larsen, S. (2007). Aspects of a psychology of the tourist experience. Scandinavian Journal of Hospitality and Tourism, 7(1), 7-18. doi:10.1080/15022250701226014 
Leech, N. L., \& Onwuegbuzie, A. J. (2007). An array of qualitative data analysis tools: A call for data analysis triangulation. School Psychology Quarterly 2007, 22(4), 557-584. doi: 10.1037/1045-3830.22.4.557

Lehto, X. Y., O’Leary, J. T., \& Morison, A. M. (2004). The effect of prior experience on vacation behaviour. Annals of Tourism Research, 31(4), 801-818.

Lewis, D., \& Bridger, D. (2001). The soul of the new consumer. London: Nicholas Brealey Publishing

Lincoln, Y. S., \& Guba, E. G. (1985). Naturalistic Inquiry. Beverly Hills, CA: Sage.

Lugosi, P. (2009). The production of hospitable space: Commercial propositions and consumer co-creation in a bar operation. Space and Culture, 12(4), 396-411. doi:10.1177/1206331209348083

Lugosi, P., \& Walls, A. R. (2013). Researching destination experiences: Themes, perspectives and challenges. Journal of Destination Marketing and Management, 2(2), 51-58. doi:10.1016/j.jdmm.2013.07.001

Lusch, R. F., Vargo, S. L., \& O’Brien, M. (2007). Competing through service: Insights from service-dominant logic. Journal of Retailing, 83(1), 5-18. doi:10.1016/j.jretai.2006.10.002

MacLeod, N., Hayes, D., \& Slater, A. (2009). Reading the landscape: The development of a typology of literary trails that incorporate an experiential design perspective. Journal of Hospitality Marketing and Management, 18(2-3), 154-172. doi:10.1080/19368620802590183

Mancas, M., \& Le Meur, O. (2013). Memorability of natural scenes: The role of attention. 20th IEEE International Conference on Image Processing (ICIP), 15-18 Sep, 196 200, Melbourne, Australia. doi: 10.1109/ICIP.2013.6738041

Mannell, R. C., \& Iso-Ahola, S. E. (1987). Psychological nature of leisure and tourism experience. Annals of Tourism Research, 14(3), 314-331. doi:10.1016/01607383(87)90105-8

Mansfeldt, O. K., Vestager, E. M., \& Iversen, M. B. (2008). Experience design in city tourism (pp. 1-212). Nordic Innovation Centre project number: 06316, Wonderful Copenhagen.

Marschall, S. (2012). Tourism and memory. Annals of Tourism Research, 39(4), 22162219. doi:10.1016/j.annals.2012.07.001

Mather, E. (2013). Novelty, attention, and challenges for developmental psychology. Frontiers in Psychology, 4 (August), 491, pp. 1-4. doi:10.3389/fpsyg.2013.00491

Mathisen, L. (2013). Staging natural environments: A performance perspective. Advances in Hospitality and Leisure, 9(2013), 163-183. doi:10.1108/S17453542(2013)0000009012 
Mehmetoglu, M., \& Engen, M. (2011). Pine and Gilmore's concept of experience economy and its dimensions: An empirical examination in tourism. Journal of Quality Assurance in Hospitality and Tourism, 12(4), 237-255. doi:10.1080/1528008X.2011.541847

Minkiewicz, J., Evans, J., \& Bridson, K. (2013). How do consumers co-create their experiences? An exploration in the heritage sector. Journal of Marketing Management, (December), 1-30. doi:10.1080/0267257X.2013.800899

Mkono, M. (2012). Using net-based ethnography (netnography) to understand the staging and marketing of "authentic african" dining experiences to tourists at Victoria Falls. Journal of Hospitality and Tourism Research, 37(2), 184-198. doi:10.1177/1096348011425502

Morgan, M. (2006). Making space for experiences. Journal of Retail and Leisure Property, 5(4), 305-313. doi:10.1057/palgrave.rlp.5100034

Morgan, M. (2007). On the sports tourist experience, International Journal of Tourism Research, 9, 361-372. doi:10.1002/jtr.637

Morgan, M., \& Xu, F. (2009). Student travel experiences: Memories and dreams. Journal of Hospitality Marketing and Management, 18(2-3), 216-236. doi:10.1080/19368620802591967

Morgan, Michael, Elbe, J., \& Curiel, J. E. (2009). Has the experience economy arrived? The views of destination managers in three visitor-dependent areas. International Journal of Tourism Research, 11, 201-216. doi:10.1002/jtr

Morse, J. M., Olson, K., \& Spiers, J. (2002). Verification strategies for establishing reliability and validity in qualitative research. International Journal of Qualitative Methods, 1(2), 13-22.

Moscardo, G. (1996). Heritage and tourism. Annals of Tourism Research, 23(2), 376397.

Mossberg, L. (2007). A marketing approach to the tourist experience. Scandinavian Journal of Hospitality and Tourism, 7(1), 59-74. doi:10.1080/15022250701231915

Mossberg, L. (2008). Extraordinary experiences through storytelling. Scandinavian Journal of Hospitality and Tourism, 8(3), 195-210. doi:10.1080/15022250802532443

Mulongo, G. (2013). Effect of active learning teaching methodology on learner participation. Journal of Education and Practice, 4(4), 157-168.

Mundy, P., \& Newell, L. (2007). Attention, joint attention, and social cognition. Current Directions in Psychological Science, 16(5), 269-274. doi:10.1111/j.14678721.2007.00518.x 
Neuhofer, B., Buhalis, D., \& Ladkin, A. (2012). Conceptualising technology enhanced destination experiences. Journal of Destination Marketing and Management, 1(12), 36-46. doi:10.1016/j.jdmm.2012.08.001

Neuhofer, B., Buhalis, D., \& Ladkin, A. (2013). High tech for high touch experiences: A case study from the hospitality industry. In L. Cantoni, \& Z. Xiang (Eds.), Information and Communication Technologies in Tourism. Proceedings of the International Conference in Innsbruck, Austria, January 22-25 (pp. 290-301). Heidelberg: Springer-Verlag.

Neuhofer, B., Buhalis, D., \& Ladkin, A. (2013). Experiences, co-creation and technology: a conceptual approach to enhance tourism experiences. In Tourism and Global Change: On the edge of something big. CAUTHE 2013 Conference Proceedings (pp. 546-555).

Niculescu, G. (2010). The new approaches of attention economy and experience economy in management of the cultural tourism. Analele Universităţii "Constantin Brâncuşi" Din Târgu Jiu, Seria Economie, (4), 152-159.

Oana, S. (2008). Tourist experiences based on intimacy. Annals of the University of Oradea, Economic Science Series, 17(4), 1197-1203.

Ocasio, W. (1997). Towards an attention-based view of the firm. Strategic Management Journal, 18, 187-206.

Ocasio, W. (2011). Attention to attention. Organization Science, 22(5), 1286-1296.

O’Dell, T. (2010). Experiencescapes. In P. O’Dell, \& T., Billing (Eds.), Experiencescapes: Tourism, culture, and economy (pp. 11-33). Koge: Copenhagen Business School Press.

O’Dell, T., \& Billing, P. (Eds.) (2005). Experiencescapes: Tourism, culture, and economy. Koge: Copenhagen Business School Press.

Oken, B. S., Salinsky, M. C., \& Elsas, S. M. (2010). Vigilance, alertness, or sustained attention: Physiological basis and measurement. Clinical Neurophysiology, 117(9), 1885-1901.

Ooi, C. (2003). Crafting tourism experiences: Managing the attention product. In The 12th Nordic Symposium on Tourism and Hospitality Research (pp. 1-26). Stavanger.

Ooi, C. (2010). A theory of tourism experiences. In P. O’Dell, \& T., Billing (Eds.), Experiencescapes: Tourism, culture, and economy (pp. 51-68). Koge: Copenhagen Business School Press.

Pagenstecher, C. (2003). The construction of the tourist gaze. How industrial was postwar German tourism? In L. Tissot (Ed.), Construction d'une industrie touristique au 19 e et 20e siècles. Perspectives internationales. Development of a Tourist Industry in the 19th and 20th Centuries. International Perspectives (pp. 373-389). Neuchâtel. 
Patterson, D., \& Bitgood, S. (1988). Some evolving principles of visitor behavior. In: A. Benefield, J.T. Roper \& S. Bitgood (Eds.), Visitor studies: Theory, research, and practice, Vol. 1 (40-50). Jacksonville, Jacksonville State Univ. Centre for Social Design.

Pearce, P. L., \& Kang, M. (2009). The effects of prior and recent experience on continuing interest in tourist settings. Annals of Tourism Research, 36(2), 172-190. doi:10.1016/j.annals.2009.01.005

Perkins, H. C., \& Thorns, D. C. (2001). Gazing or performing. International Sociology. doi:10.1177/0268580901016002004

Pikkemaat, B., \& Schuckert, M. (2007). Success factors of theme parks: An exploratory study. Tourism, 55(2), 197-208.

Pine, B. J., \& Gilmore, J. H. (1999). The experience economy: Work is theatre and every business a stage. Boston: Harvard Business School Publishing.

Posner, M. I., Rothbart, M., \& Rueda, M. R. (2014). Developing attention and selfregulation in childhood. In A. C. Nobre \& S. Kastner (Eds.), The Oxford handbook of attention (pp. 541-569). Oxford: Oxford University Press.

Potts, J., Hartley, J., Banks, J., Burgess, J., Cobcroft, R., Cunningham, S., \& Montgomery, L. (2008). Consumer co-creation and situated creativity. Industry and Innovation, 15(5), 459-474. doi:10.1080/13662710802373783

Poulsson, S. H. G., \& Kale, S. H. (2004). The experience economy and commercial experiences. The Marketing Review, 4, 267-277.

Prahalad, C. K., \& Ramaswamy, V. (2003). The new frontier of experience innovation. MIT Sloan Management Review, 44(4), 11-18.

Prahalad, C. K., \& Ramaswamy, V. (2004). Co-creation experiences: The next practice in value creation. Journal of Interactive Marketing, 18(3), 5-14. doi:10.1002/dir.20015

Prebensen, N. K., \& Foss, L. (2011). Coping and co-creating in tourist experiences. International Journal of Tourism Research, 13, 54-67. doi:10.1002/jtr.799

Prebensen, N. K., Vittersø, J., \& Dahl, T. I. (2013a). Value co-creation significance of tourist resources. Annals of Tourism Research, 42, 240-261. doi:10.1016/j.annals.2013.01.012

Prebensen, N. K., Woo, E., \& Uysal, M. S. (2013b). Experience value: Antecedents and consequences. Current Issues in Tourism, (April), 1-19. doi:10.1080/13683500.2013.770451

Quan, S., \& Wang, N. (2004). Towards a structural model of the tourist experience: An illustration from food experiences in tourism. Tourism Management, 25(3), 297305. doi:10.1016/S0261-5177(03)00130-4 
Ramaswamy, V. (2011). It's about human experiences... and beyond, to co-creation. Industrial Marketing Management, 40(2), 195-196. doi:10.1016/j.indmarman.2010.06.030

Ramaswamy, V., \& Gouillart, F. (2010). The power of co-creation. New York: Free Press.

Reisberg, D., Heuer, F., McLean, J., \& O'Shaughnessy, M. (1988). The quantity, not the quality, of affect predicts memory vividness. Bulletin of the Psychonomic Society, $26(2), 100-103$.

Richards, G. (2010). Tourism development trajectories - from culture to creativity? Tourism and Management Studies, 6, 9-15.

Richards, G. (2011). Creativity and tourism. Annals of Tourism Research, 38(4), 12251253. doi:10.1016/j.annals.2011.07.008

Richards, G., \& Wilson, J. (2006). Developing creativity in tourist experiences: A solution to the serial reproduction of culture? Tourism Management, 27(6), 12091223. doi:10.1016/j.tourman.2005.06.002

Richards, G., \& Marques, L. (2012). Exploring creative tourism. Journal of Tourism Consumption and Practice, 4(2), 1-11.

Rihova, I., Buhalis., D., Moital, M., \& Gouthro, M. B. (2014). Conceptualising customerto-customer value co-creation in tourism. International Journal of Tourism Research. doi:10.1002/jtr.1993

Rihova, I., Buhalis, D., Moital, M., \& Gouthro, M. B. (2013). Social layers of customerto-customer value co-creation. Journal of Service Management, 24(5), 553-566. doi:10.1108/JOSM-04-2013-0092

Ritchie, J., \& Lewis, J. (Eds.) (2003). Qualitative research practice: A guide for social science students and researchers. London: Sage

Robinson, P. (2001). Attention and memory during SLA. In C. J. Doughty, \& M. H. Long (Eds.), The handbook of second language acquisition (pp. 631-678). Oxford: Blackwell Publishing Ltd. doi: 10.1002/9780470756492.ch19

Ryan, C. (2000). Tourist experiences, phenomenographic analysis, post-postivism and neural network software. International Journal of Tourism Research, 2(2), 119-131.

Sarter, M., Givens, B., \& Bruno, J. P. (2001). The cognitive neuroscience of sustained attention: Where top-down meets bottom-up. Brain Research Reviews, 35(2), 146160. doi:10.1016/S0165-0173(01)00044-3

Scerif, G, \& Wu, R. (2014). Developmental disorders: A window onto attention dynamics. In A. C. Nobre \& S. Kastner (Eds.), The Oxford handbook of attention (pp. 893-926). Oxford: Oxford University Press. 
Schmitt, B. (2010). Experience marketing: Concepts, frameworks and consumer insights. Foundations and Trends in Marketing, 5(2), 55-112. doi:10.1561/1700000027

Schmitt, B. (1999). Experiential marketing. Journal of Marketing Management, 15(1-3), 53-67. doi:10.1362/026725799784870496

Scott, N., Laws, E., \& Boksberger, P. (2009). The marketing of hospitality and leisure experiences. Journal of Hospitality Marketing and Management, 18(2-3), 99-110. doi:10.1080/19368620802590126

Shaffer, D. R., \& Kipp, K. (2014). Developmental psychology: Childhood and adolescence (9th ed.). Belmont: Cengage Learning.

Snell, Y. S. L. S. (1999). Interactive lecturing: Strategies for increasing participation in large group presentations. Medical Teacher, 21(1), 37-42. doi:10.1080/01421599980011

Stangor, C., Jhangiani, R., \& Tarry, H. (2014). Principles of Social Psychology - 1st International Edition. Available online: http://opentextbc.ca/socialpsychology/ [Site accessed 16 September 2015]

Sternberg, E. (1997). The iconography of the tourism experience. Annals of Tourism Research, 24(4), 951-969. doi:10.1016/S0160-7383(97)00053-4

Surra, C. A., \& Ridley, C. A. (1991). Multiple perspectives on interaction: Participants, peers, and observers. In B. M. Montgomery \& S. Duck, Studying Interpersonal Interaction (pp. 35-55). New York, NY: The Guilford Press.

Sylwester, R., \& Cho, J.-Y. (1993). What brain research says about paying attention. Educational Leadership, 50(4), 71-75.

Tan, S.-K., Luh, D.-B., \& Kung, S.-F. (2014). A taxonomy of creative tourists in creative tourism. Tourism Management, 42, 248-259. doi:10.1016/j.tourman.2013.11.008

Tan, S.-K, Kung, S.-F., \& Luh, D.-B. (2013). A model of “creative experience” in creative tourism. Annals of Tourism Research, 41, 153-174. doi:10.1016/j.annals.2012.12.002

Thompson, K. (2008). Tourist decision making and the service centred dominant logic of marketing, in CAUTHE, Proceedings of the 18th Annual CAUTHE Conference, Richardson, S., Fredline, L., Patiar, A., \& Ternel, M., (Eds.) CD-ROM, Griffith University, Gold Coast, 11-14 February. ISBN: 978-1-921291-33-3. (pp. 1-4).

Tung, V. W. S., \& Ritchie, J. R. B. (2011a). Exploring the essence of memorable tourism experiences. Annals of Tourism Research, 38(4), 1367-1386. doi:10.1016/j.annals.2011.03.009

Tung, V. W. S., \& Ritchie, J. R. B. (2011b). Investigating the memorable experiences of the senior travel market: An examination of the reminiscence bump. Journal of 
Travel and Tourism Marketing, 28(3), 331-343. doi:10.1080/10548408.2011.563168

Urry, J. (1990). The Tourist Gaze. London: Sage Publications Ltd.

Vargo, S. L., \& Lusch, R. F. (2004). Evolving to a new dominant logic. Journal of Marketing, 68(1), 1-17.

Vargo, S. L., \& Lusch, R. F. (2008). Service-dominant logic: Continuing the evolution. Journal of the Academy of Marketing Science, 36, 1-10. doi:10.1007/s11747-0070069-6

Vargo, S. L., Maglio, P. P., \& Akaka, M. A. (2008). On value and value co-creation: A service systems and service logic perspective. European Management Journal, 26(3), 145-152. doi:10.1016/j.emj.2008.04.003

Verhoef, P. C., Lemon, K. N., Parasuraman, A., Roggeveen, A., Tsiros, M., \& Schlesinger, L. A. (2009). Customer experience creation: Determinants, dynamics and management strategies. Journal of Retailing, 85(1), 31-41. doi:10.1016/j.jretai.2008.11.001

Volo, S. (2009). Conceptualizing experience: A tourist based approach. Journal of Hospitality Marketing and Management, 18(2-3), 111-126. doi:10.1080/19368620802590134

Voss, C. (2004). Trends in the experience and service economy: The experience profit cycle (executive summary). Centre for Operations and Technology. London: Management London Business School.

Walle, A. H. (1997). Quantitative versus qualitative tourism research. Annals of Tourism Research, 24(3), 524-536. doi: 10.1016/s0160-7383(96)00055-2

Walls, A. R., Okumus, F., Wang, Y., \& Kwun, D. J.-W. (2011). An epistemological view of consumer experiences. International Journal of Hospitality Management, 30(1), 10-21. doi:10.1016/j.ijhm.2010.03.008

Wikstrom, S. R. (2008). A consumer perspective on experience creation. Journal of Customer Behaviour, 7(1), 31-50.

Wright, R. K. (2010). 'Been there, done that': Embracing our post-trip experiential recollections through the social construction and subjective consumption of personal narratives. In Morgan, M., Lugosi, P., \& Ritchie, J. R. B. (Eds.), The tourism and leisure experience: Consumer and managerial perspectives (pp. 117-136). Bristol: Channel View Publications.

Yadav, M. S., Prabhu, J. C., \& Chandy, R. K. (2007). Managing the future: CEO attention. Journal of Marketing, 71(October), 84-101. 